\title{
Lymphocytotoxic antibodies in systemic lupus erythematosus: studies of their temperature dependence, binding characteristics, and specificity in vitro
}

\author{
P W PEAKE, J D GREENSTEIN, V TIMMERMANS, L GAVRILOVIC, \\ AND J A CHARLESWORTH \\ From the Division of Medicine, Prince Henry Hospital, Little Bay, New South Wales, Australia
}

SUMMARY The lymphocytotoxicity of 33 lupus sera was tested against purified helper/inducer (OKT4) and cytotoxic/suppressor (OKT8) subsets of T lymphocytes at $15^{\circ} \mathrm{C}$ and $37^{\circ} \mathrm{C}$ in vitro. There was significantly less killing of both OKT4 and OKT8 cells at $37^{\circ} \mathrm{C}(\mathrm{p}<0.001$ and $\mathrm{p}<0 \cdot 01)$ and the ratio of $\mathrm{OKT} 4 / \mathrm{OKT} 8$ cell killing at $15^{\circ} \mathrm{C}(1 \cdot 39(0 \cdot 73)$; mean (SD)) was different from that observed at $37^{\circ} \mathrm{C}(0.79(0.42))(\mathrm{p}<0.001)$. OKT4 killing was greater than OKT8 killing in 21 out of 33 sera at $15^{\circ} \mathrm{C}$, while 22 of these sera showed predominantly OKT8 cytotoxicity at $37^{\circ} \mathrm{C}$. The relation between the OKT4/OKT8 cell ratio and OKT4/OKT8 serum killing was examined in 22 patients at both temperatures: a significant inverse correlation was observed at $37^{\circ} \mathrm{C}(\mathrm{r}=-0.53$; $\mathrm{p}=0.015)$ but not at $15^{\circ} \mathrm{C}(\mathrm{p}>0.05)$. The addition of metabolic and cytoskeletal inhibitors increased cytotoxicity at $37^{\circ} \mathrm{C}$, but not IgM surface binding. A Scatchard binding analysis of the reaction at $15^{\circ} \mathrm{C}$ showed that large numbers of antibody molecules were bound to both subsets, with a low average dissociation constant of $\leqslant 6 \times 10^{-8} \mathrm{~mol} / \mathrm{l}$, and electrophoretic blotting indicated that the target surface antigens varied in type and number among individual lymphocytotoxic sera. The demonstration of temperature dependent, tight binding between lymphocytotoxic antibody and variable antigens on the $T$ cell surface emphasises the potential for this phenomenon to affect lymphocyte function in vivo in patients with systemic lupus erythematosus.

Key words: lymphocyte surface antigens, Scatchard analysis, metabolic inhibition.

More than $90 \%$ of sera from patients with systemic lupus erythematosus (SLE) show toxicity for normal peripheral blood lymphocytes in vitro. ${ }^{1}$ This lymphocytotoxic activity (LCA) resides predominantly (but not exclusively) in the IgM fraction and is maximal at $15^{\circ} \mathrm{C}$. The temperature dependence is thought to represent a compromise between the warm incubation requirements of complement mediated lympholysis and the optimal binding conditions for IgM class lymphocyte antibody (i.e., $\left.4^{\circ} \mathrm{C}\right){ }^{2}$ Studies of the specificity of LCA in SLE have produced conflicting reports. Some workers have shown reactivity against the suppressor $\mathrm{T}$ cell subset

Accepted for publication 29 February 1988.

Correspondence to Dr J A Charlesworth, Department of Medicine, Clinical Sciences Building, Prince Henry Hospital, Little Bay, NSW 2036, Australia. (as defined by either functional testing or surface markers) ${ }^{3}$ while others have observed cytotoxicity against the helper/inducer population. ${ }^{4} \mathrm{~A}$ recent study showed that the circulating $\mathrm{T}$ cell subset ratio correlated with the subset specificity of LCA in lupus sera ${ }^{5}$; observations were made only at $15^{\circ} \mathrm{C}$, however. Little is known about the specificity of serum LCA at $37^{\circ} \mathrm{C}$, or indeed the influence of assay temperature on subset killing. The kinetics of antibody binding and the nature of the surface antigens involved are also unclear. These issues must be resolved in order to ascribe more confidently a physiological role to this reaction.

In this study we have examined in detail the temperature dependence and specificity of the reaction. Scatchard analysis was used to estimate the dissociation constant of the interaction between 
lymphocyte and autoantibody, as well as the quantity of antibody bound. The ability of various metabolic inhibitors to restore killing at $37^{\circ} \mathrm{C}$ was also investigated. Finally, we used electrophoretic blotting techniques to demonstrate the variability, within a group of serum samples with high titre LCA, of the number and molecular weight of lymphocyte surface antigens reactive with these IgM autoantibodies.

\section{Patients and methods}

PATIENTS

Serum samples were obtained from 33 patients with $\mathrm{SLE}^{6}$ and eight healthy volunteers. Aliquots were stored at $-20^{\circ} \mathrm{C}$ until analysed.

MEASUREMENT OF LCA

$T$ lymphocytes were purified from peripheral blood by Ficoll-Hypaque centrifugation after fractionation over nylon wool. Subsets were prepared by incubation of purified $T$ cells with monoclonal antiOKT8 or anti-OKT4 (Ortho) antibodies $\left(5 \mu \mathrm{l} / 10^{6}\right.$ cells in complement fixation diluent (CFD; Oxoid)) for 30 minutes at $20^{\circ} \mathrm{C}$, followed by the addition of an equal volume of rabbit serum (as a source of complement) and incubation for 90 minutes at $37^{\circ} \mathrm{C}$. Lysed cells were removed by Ficoll-Hypaque centrifugation. Cell purity was approximately $90 \%$ as confirmed by immunoperoxidase staining with antiOKT4 and anti-OKT8 antibodies and peroxidase conjugated antimouse immunoglobulin (Dako).

Serum samples were tested for LCA against $\mathrm{T}$ cells and purified subsets at both $15^{\circ} \mathrm{C}$ and $37^{\circ} \mathrm{C}$. The procedure was a modification of that described by Terasaki and McClelland. ${ }^{7}$ Specifically, $20 \mu \mathrm{l}$ of cell suspension $\left(1 \times 10^{6}\right.$ cells $\left./ \mathrm{ml}\right)$ in CFD was premixed with $20 \mu \mathrm{l}$ of patient or control serum before the addition of $40 \mu \mathrm{l}$ of rabbit serum. The mixture was incubated for 60 minutes at $37^{\circ} \mathrm{C}$ or 180 minutes at $15^{\circ} \mathrm{C}$ before the determination of percentage cell lysis by a standard trypan blue exclusion technique.

ANALYSIS OF IgM BINDING TO THE

LYM PHOCYTE SURFACE

Affinity purified sheep antihuman IgM (Silenus) was labelled with ${ }^{125}$ I (Amersham) by the lactoperoxidase method. ${ }^{8}$ This labelled antibody showed only one precipitin line against normal human serum (NHS) in a standard double diffusion assay in agarose.

Purified lymphocytes and test sera were diluted in $10 \%$ decomplemented fetal calf serum (Commonwealth Serum Laboratory) in CFD with $0.05 \%$ sodium azide. Duplicate tubes containing $200 \mu \mathrm{l}$ of lymphocytes $\left(5 \times 10^{6} / \mathrm{ml}\right.$ of OKT3, OKT4, or OKT8 positive cells) were incubated with an equal volume of diluted serum at $15^{\circ} \mathrm{C}$ for two hours. (Preliminary? experiments showed that binding equilibrium was reached under these conditions.) The cells were? then layered onto $2 \mathrm{ml}$ of $5 \%$ bovine serum albumir in CFD/azide, and unbound molecules separated b centrifugation at $1000 \mathrm{~g}$ for five minutes. The celf pellet was resuspended in $400 \mu \mathrm{l}$ of a 1 in $10 \circledast$ dilution of ${ }^{125}$ I anti-IgM in fetal calf serum/CFD/azide and incubated for two hours. Finally, the cells wer 5 again layered into $5 \%$ bovine serum albuminiseparated by centrifugation, and the tip of the polystyrene tube containing the cellular pellet excise and counted in a gammacounter. Molecules of IgM bound to the cell surface were determined bi comparison with the binding of labelled antibody to known amounts of IgM. (Complexed antibody waș separated from unbound molecules by precipitation with $10 \%$ polyethylene glycol (mol. wt 6000$)$ an centrifugation at $2000 \mathrm{~g}$ for 30 minutes.

Control experiments showed negligible binding i i cell free polystyrene tubes and all solutions werक्ष centrifuged at $2200 \mathrm{~g}$ for 30 minutes before assay t $\Phi^{\nexists}$ remove aggregated material. The reversibility of IgM surface binding was determined by the ppolonged (i.e., up to eight hours) incubation of cello human serum free medium after preincubation whth serum with positive LCA (as above).

IgM concentration was measured by radias immunodiffusion using a standard control serur

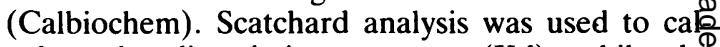
culate the dissociation constant $(\mathrm{Kd})$, while the concentration of binding sites per cell was determine with the additional use of Avogadro's number an $\bar{\Phi}$ the quantity of cells per tube.

CHARACTERISATION OF LYMPHOCYTE

SURFACE ANTIGENS

Lymphocytes were washed in CFD/azide and incu bated with normal or SLE sera $\left(10^{8}\right.$ cells/40 serum) for 60 minutes at $4^{\circ} \mathrm{C}$. The cells were resuspended in an additional $200 \mu \mathrm{l}$ CFD/azide again separated by centrifugation, and the lympho cytotoxic reactivity of the supernatant (i.e., normal and SLE sera) compared with that of unabsorbed normal and patient sera. These absorbef samples were also used as probes for the experiments described below.

Samples of normal donor lymphocytes $\left(1.5 \times 10^{85}\right.$ were boiled in $5 \mathrm{ml}$ of reducing sodium dodect sulphate (SDS) buffer, passed through a $0.22 \mu \mathrm{mit}$ filter (Amicon) and centrifuged for 60 minutes $a_{0}^{a b}$ $35000 \mathrm{rpm}$ before polyacrylamide gel electrophoresis ${ }^{9}$ in SDS on $12 \%$ agarose gels $(16 \times 0.1 \mathrm{~cm})$ one track was reserved for SDS-6H (Sigmant molecular weight markers. Samples were electrôे 
phoresed overnight at a constant 60 volts. Electrophoretic transfer to nitrocellulose was performed according to the method of Towbin et $a l^{10}$ in $0.025 \mathrm{M}$ trometamol (TRIS)-glycine buffer with $20 \% \mathrm{v} / \mathrm{v}$ methanol for four hours at $70 \mathrm{~V}$ and adjacent strips of nitrocellulose then probed with absorbed or nonabsorbed sera. Specifically, aliquots of these sera $(20 \mu \mathrm{l} / 4 \mathrm{ml}$ of incubation buffer) were incubated and shaken overnight before the detection of bound IgM with monospecific rabbit antibody (Dako) and an affinity purified goat antirabbit alkaline phosphatase conjugate (Bio Rad). Both antibodies were used at room temperature for 60 minutes in incubation buffer (i.e., $0.02 \mathrm{M}$ trometamol buffer with $0.5 \mathrm{M}$ $\mathrm{NaCl}, 1 \%$ w/v gelatine, and $0.05 \%$ Tween 20 ). Colour development was performed with nitroblue tetrazolium and 5-bromo-4-chloro-3-indolyl phosphate in a bicarbonate buffer at pH 9.8. Experiments with strips stained with decreasing amounts of serum showed that colour intensity was responsive to the serum concentration for most bands at this proportion of serum to lymphocyte antigen.

\section{EFFECT OF METABOLIC INHIBITORS ON}

LYMPHOCYTE KILLING IN VITRO

The metabolic inhibitors azide, fluoride, and arsenite were prepared as the sodium salts in CFD and tested for intrinsic lymphocytotoxicity before use in experiments. The highest concentrations that gave minimal toxicity (i.e., $<5 \%$ ) were used $-0.05 \% \mathrm{NaF}, 0.05 \%$ $\mathrm{NaN}_{3}$, and $0.01 \% \mathrm{NaAsO}_{2}$. Purified $\mathrm{T}$ cells were washed three times in CFD or CFD/inhibitor and resuspended in the same solution at a concentration of $2 \times 10^{6}$ cells $/ \mathrm{ml}$. They were then incubated with either normal or SLE sera at $15^{\circ} \mathrm{C}(180$ minutes) or $37^{\circ} \mathrm{C}$ ( 60 minutes) in the presence of rabbit serum (decomplemented for some experiments), and the percentage cell lysis determined by standard methods. Colchicine, lidocaine, and dibucaine were also prepared in CFD and incubation conditions selected by the same criteria as those used above: $2 \times 10^{6}$ $\mathrm{T}$ cells $/ \mathrm{ml}$ were incubated with $5 \times 10^{-5} \mathrm{M}$ colchicine, $50 \mu \mathrm{g} / \mathrm{ml}$ lidocaine, and $5 \mu \mathrm{g} / \mathrm{ml}$ dibucaine.

The effect of metabolic inhibitors on the binding of IgM to the lymphocyte surface was measured by Scatchard analysis.

STATISTICAL ANALYSIS

A paired Student's $t$ test was used to calculate the significance of differences in the binding kinetics. Scatchard plots were analysed by linear regression and calculation of the ' $r$ ' coefficient.

The difference between percentage killing of OKT4 and OKT8 cells at $15^{\circ} \mathrm{C}$ and $37^{\circ} \mathrm{C}$ was analysed by a Wilcoxon match pair test. The difference between OKT4/OKT8 killing at $15^{\circ} \mathrm{C}$ and $37^{\circ} \mathrm{C}$ was analysed by an unpaired Student's $t$ test, and the correlation between OKT4/OKT8 cell ratio and $\mathrm{OKT} 4 / \mathrm{OKT} 8$ killing at $15^{\circ} \mathrm{C}$ and $37^{\circ} \mathrm{C}$ was also examined by linear regression analysis with calculation of the $r$ coefficient.

\section{Results}

TEMPERATURE DEPENDENCE OF

CYTOTOXICITY

The percentage lymphocytotoxicity of 33 SLE sera, tested against purified OKT4 positive cells, was significantly greater at $15^{\circ} \mathrm{C}$ than at $37^{\circ} \mathrm{C}: 53(26) \%$ (mean (SD)) and $18(10) \%$ respectively $(\mathrm{p}<0.001)$. In comparison, mean OKT8 cell killing was 45 $(28) \%$ and $28 \quad(18) \% \quad(p<0 \cdot 01)$. The ratios of OKT4/OKT 8 cells killed by test sera at $15^{\circ} \mathrm{C}$ and $37^{\circ} \mathrm{C}$ were significantly different: $1.39(0.73)$ at $15^{\circ} \mathrm{C}$ (mean (SD)) and $0.79(0.42)$ at $37^{\circ} \mathrm{C}(\mathrm{p}<0.001)$. At $15^{\circ} \mathrm{C}, 64 \%(21 / 33)$ of sera showed OKT4 killing greater than OKT8 killing, while at $37^{\circ} \mathrm{C}, 67 \%$ (22/33) of sera showed predominantly OKT 8 cytotoxicity. There was also a significant inverse correlation between the OKT4/OKT8 serum killing and the patients' $\mathrm{OKT} 4 / \mathrm{OKT} 8$ cell ratio at $37^{\circ} \mathrm{C}$ $(\mathrm{r}=-0.53, \mathrm{p}=0.015)$, but not at $15^{\circ} \mathrm{C}$.

\section{ANALYSIS OF IgM BINDING TO TARGET L Y M P H O Y T E S}

Preliminary experiments showed $(a)$ The precipitin reaction between IgM (contained in dilutions of NHS) and ${ }^{125}$ I anti-IgM was linear for the range $0-0.15 \mu \mathrm{g}(\mathrm{r}=0.98)$. (b) The binding between IgM coated $\mathrm{T}$ lymphocytes (i.e., by prior incubation with sera with positive LCA) and radiolabelled anti-IgM was maximal after two hours' incubation and with a $1 / 100$ dilution of antibody. IgM from cytotoxic sera, after chromatographic separation from $\mathrm{IgG}$, gave similar results. (c) There was a linear relation between surface bound IgM and the proportion of target lymphocytes that had been prereacted with lymphocytotoxic lupus sera (Fig. 1).

\section{Effect of incubation temperature on binding of lymphocytotoxic antibody}

Fig. 2 shows data for a typical lupus serum. Binding was maximal for all dilutions (i.e., 1/10, 1/100, $1 / 1000$ ) after two hours' incubation at either $4^{\circ} \mathrm{C}$ or $15^{\circ} \mathrm{C}$. There was variability in binding at $37^{\circ} \mathrm{C}$, and all sera showed a substantial decrease in bound IgM compared with that observed at lower temperatures. NHS showed a similar pattern of temperature dependence for antibody binding, although at each concentration less antibody was bound from NHS than from SLE sera. 


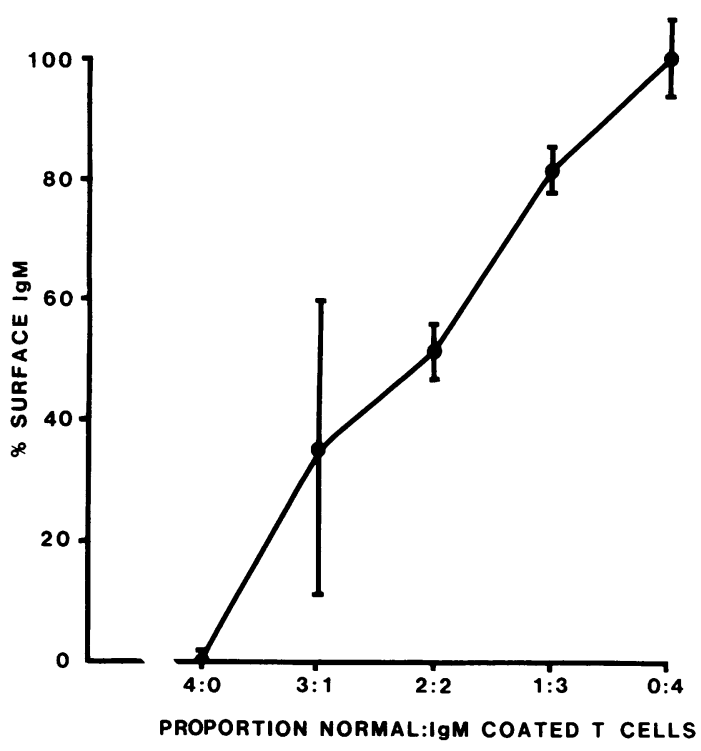

Fig. 1 Relation between binding of IgM to the lymphocyte surface and the proportion of target cells that had been prereacted with lymphocytotoxic lupus sera. Surface IgM is expressed as a percentage of that observed when all target cells had been prereacted with cytotoxic serum. Mean (SD) values are shown.

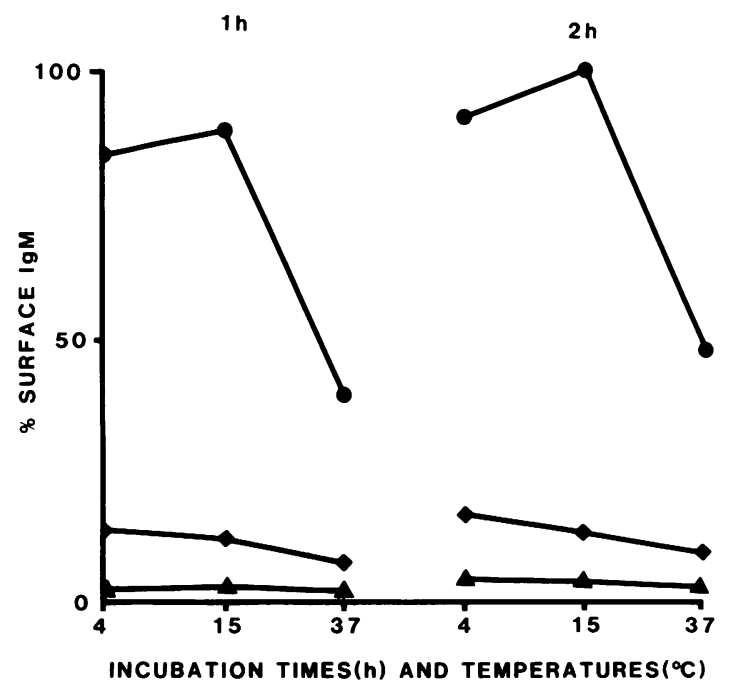

Fig. 2 Effect of variations in incubation time $(h)$ and temperature $\left({ }^{\circ} \mathrm{C}\right)$ on the amount of IgM bound to the lymphocyte surface. Results for one typical lupus serum are shown (expressed in terms of maximum IgM binding attained).$=1 / 10$ dilution, $\nabla=1 / 100$ dilution, $\Delta=1 / 1000$ dilution.
Dissociation of surface bound IgM

Fig. 3 shows the effect of prolonged incubation? (at $15^{\circ} \mathrm{C}$ ) of IgM coated $\mathrm{T}$ lymphocytes in human serum free medium. Cells that had been preincubated? with either NHS or lupus sera showed an initial rapid fall in bound antibody (i.e., over the first two hours) followed by a slower fall over the next six hours. Overnight incubation resulted in unacceptably high cell mortality.

Measurement of dissociation constant $(K d)$ and surface IgM concentration

Fig. 4 shows the effect of variation of serumb concentration (i.e., NHS and SLE) on IgM binding to OKT4 and OKT8 positive cells (at $15^{\circ} \mathrm{C}$ ); an initial increase in IgM binding was followed by $\mathrm{a}^{\circ}$ plateau. Table 1 shows values obtained for $\mathrm{Kd}$ and surface IgM concentrations with six lupus sera and two NHS pools. The dissociation constants for both? OKT4 and OKT8 positive cells were similar for the $\overrightarrow{c s}$ two groups of sera, though the concentration of surface bound IgM was generally much greater for cells incubated with SLE sera (Table 1).

\section{DETECTION OF I GM REACTIVE}

LYMPHOCYTE SURFACE ANTIGENS BY

E L E C T RO B LOTTING

When different pools of normal lymphocytes wereo probed with several SLE and normal sera consistents patterns for each serum were found, but between different sera there were differing patterns of IgMo reactive lymphocyte antigens. While some bands

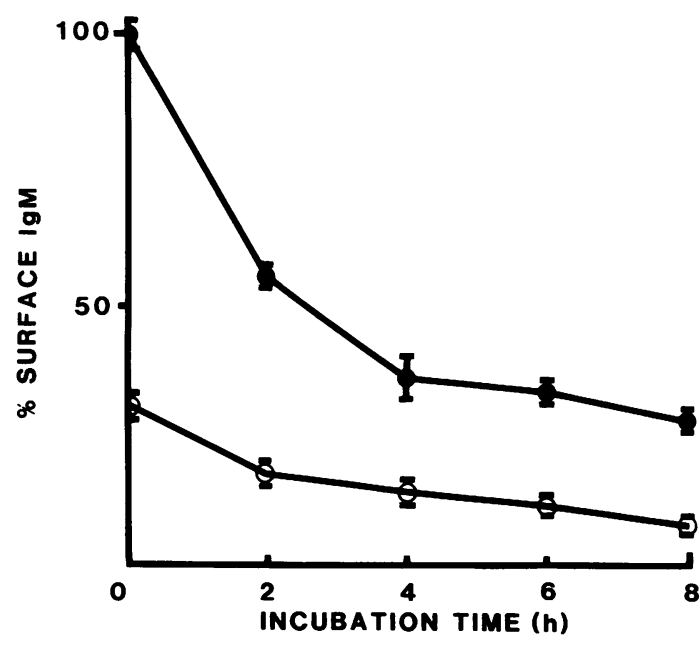

Fig. 3 Effect on surface bound IgM of prolonged incubation of prereacted T lymphocytes in serum free medium. Mean (SD) values are shown forcells preincubated with SLE sera (O) and normal human serum (O). 
were shared between SLE and normal sera, additional antigens (generally in higher concentration) were observed with the SLE sera. Preabsorption of six SLE and six normal sera with normal lymphocytes led to a significant reduction in some band densities (on nitrocellulose) in SLE sera but not in normal sera (Fig. 5). Three of the six SLE serum samples showed a loss of one band of 90000 kilodaltons and another three showed a loss of a band of approximately 34000 kilodaltons. No single band was lost by all of the six sera after preabsorption (Table 2).

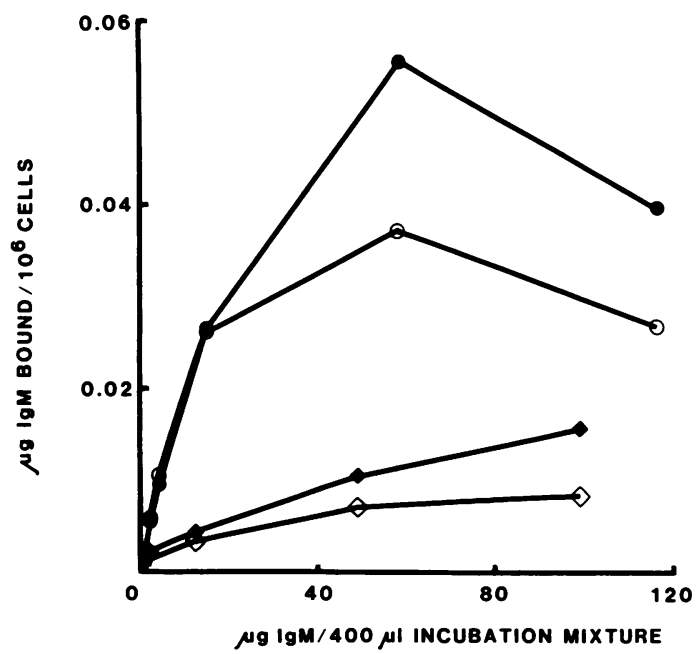

Fig. 4 Effect of variation of IgM concentration on the amount of IgM bound to the lymphocyte surface.

, $\mathrm{O}=$ OKT4, OKT8 cells incubated with SLE sera; $\checkmark=O K T 4, O K T 8$ cells incubated with normal human serum.
EFFECT OF METABOLIC INHIBITORS ON LYMPHOCYTOTOXIC ACTIVITY

Table 3 shows the LCA of six normal sera and six SLE sera when incubated with normal T lymphocytes in the presence of azide, fluoride, arsenite, colchicine, lidocaine, and dibucaine. There was a significant increase in the percentage of cells lysed at $37^{\circ} \mathrm{C}$ by

Table 2 Molecular weights of surface antigens reactive with IgM from SLE sera

\begin{tabular}{|c|c|c|c|c|c|}
\hline \multicolumn{6}{|l|}{ Serum } \\
\hline$A$ & $B$ & $C$ & $D$ & $E$ & $F$ \\
\hline 40000 & $\begin{array}{r}125000 \\
62000 \\
19000\end{array}$ & $\begin{array}{r}110000 \\
65000 \\
33000 \\
11500 \\
10000\end{array}$ & $\begin{array}{l}90000 \\
35000 \\
16500 \\
13500\end{array}$ & 90000 & $\begin{array}{l}90000 \\
34000 \\
27000\end{array}$ \\
\hline
\end{tabular}

Table 3 Effect of various inhibitors on lymphocytotoxicity at $15^{\circ} \mathrm{C}$ and $37^{\circ} \mathrm{C} \dagger$

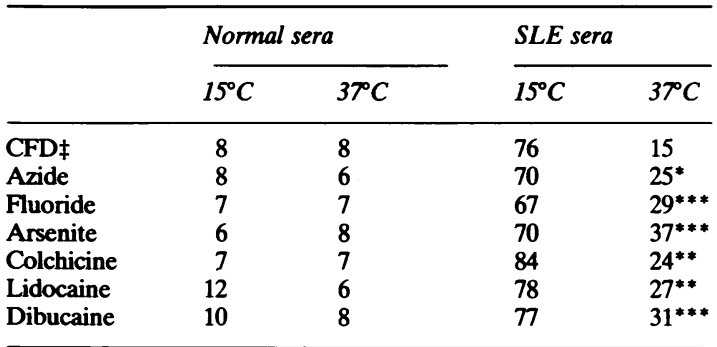

${ }^{*} \mathrm{p}<0.025 ;{ }^{* *} \mathrm{p}<0.002 ;{ }^{* * *} \mathrm{p}<0.001$ (compared with complement fixation diluent).

$t_{n}=6$ for each group. Data shown as mean percentage of cells lysed.

$\ddagger C F D=$ complement fixation diluent.

Table 1 Binding characteristics of IgM lymphocytotoxic antibodies for OKT4 and OKT8 positive cells

\begin{tabular}{|c|c|c|c|c|c|c|}
\hline \multirow[t]{2}{*}{ Serum } & \multicolumn{3}{|l|}{ OKT4 cells } & \multicolumn{3}{|l|}{ OKT8 cells } \\
\hline & $K d(\mathrm{molll})$ & $\begin{array}{l}\text { IgM molecules/ } \\
\text { OKT4 } \text { cell }^{*}\end{array}$ & $\begin{array}{l}\text { LCA on } \\
\text { OKT4 cells }{ }^{\dagger}\end{array}$ & $K d(\mathrm{~mol} / \mathrm{l})$ & $\begin{array}{l}\text { IgM molecules/ } \\
O K T 8 \text { cell }^{*}\end{array}$ & $\begin{array}{l}\text { LCA on } \\
\text { OKT8 cells }{ }^{\dagger}\end{array}$ \\
\hline NHS 1 & $\begin{array}{l}2.5 \times 10^{-8} \\
2.9 \times 10^{-8}\end{array}$ & $\begin{array}{r}12700 \\
7300\end{array}$ & $\begin{array}{l}0 \\
0\end{array}$ & $\begin{array}{l}3.2 \times 10^{-x} \\
1.9 \times 10^{-8}\end{array}$ & $\begin{array}{r}7100 \\
19300\end{array}$ & $\begin{array}{l}0 \\
3\end{array}$ \\
\hline $\begin{array}{r}\text { SLE } 1 \\
2 \\
3 \\
4 \\
5 \\
6 \\
6\end{array}$ & $\begin{array}{l}2.7 \times 10^{-8} \\
6.0 \times 10^{-8} \\
3.2 \times 10^{-8} \\
1.6 \times 10^{-8} \\
2.3 \times 10^{-8} \\
1.7 \times 10^{-8}\end{array}$ & $\begin{array}{l}11200 \\
46100 \\
96100 \\
50300 \\
60600 \\
29700\end{array}$ & $\begin{array}{l}29 \\
66 \\
28 \\
62 \\
18 \\
22\end{array}$ & $\begin{array}{l}2.1 \times 10^{-8} \\
3.5 \times 10^{-8} \\
5.3 \times 10^{-8} \\
5.8 \times 10^{-8} \\
5.8 \times 10^{-8} \\
3.7 \times 10^{-8}\end{array}$ & $\begin{array}{r}178600 \\
74500 \\
96900 \\
49700 \\
31100 \\
31000\end{array}$ & $\begin{array}{r}25 \\
24 \\
21 \\
24 \\
9 \\
18\end{array}$ \\
\hline
\end{tabular}

*Assuming equal numbers of molecules per cell.

†Expressed as percentage cell lysis. Normal $\leqslant 5 \%$. 
SLE ser : when incubated in the presence of each of these inhibitors compared with cells suspended in CFD alone. The cytotoxicity of the inhibitors, with and without test sera and in the presence of decomplemented rabbit serum, was not significant. In general, these agents did not significantly affect

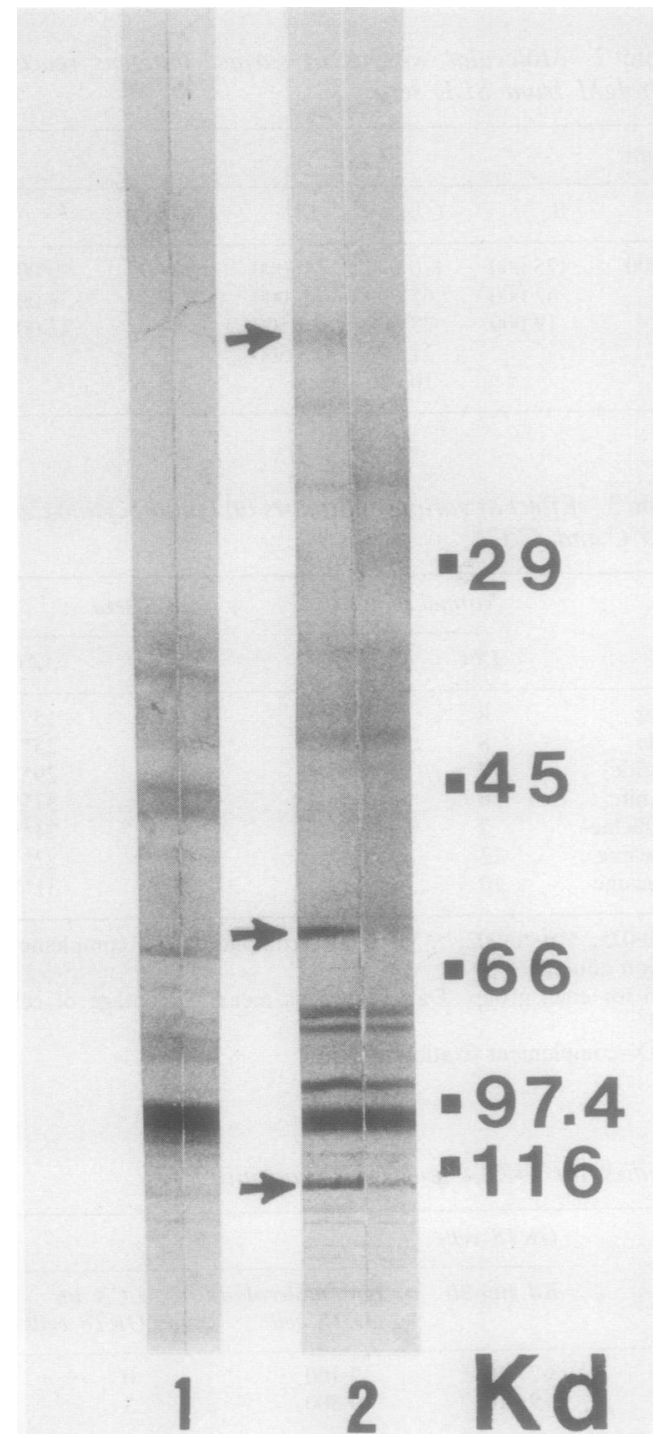

Fig. 5 IgM reactive lymphocyte antigens in normal (track 1) and SLE (track 2-patient B, Table 2) sera, as separated on reduced sodium dodecyl sulphate gels. The left track was derived from unabsorbed serum, the right from serum absorbed with viable cells. Bands $(\rightarrow)$ at 125,62 , and 19 kilodaltons are much reduced in $B$ absorbed serum. Molecular weight markers are shown as kilodaltons $(K d)$. the amount of IgM bound to the lymphocyte surface. though the amount bound at $37^{\circ} \mathrm{C}$ wase. significantly less than at $15^{\circ} \mathrm{C}(\mathrm{p}<0.05$ for all incubation media, with both NHS and SLE sera). There was no correlation between the amount of IgM binding to the cell surface after incubation with흠 SLE or normal serum and the lymphocytotoxicity of? that serum.

\section{Discussion}

This study demonstrated significant differences in $\vec{\omega}$ the T lymphocyte subset specificity of lymphocytotoxic lupus sera at $15^{\circ} \mathrm{C}$ and $37^{\circ} \mathrm{C}$. At $15^{\circ} \mathrm{C}$ (theo temperature at which most studies are performed toxicity was greater for OKT4 cells. No significante correlation was observed between the patients $\mathrm{N}$ OKT4/OKT8 cell ratio and OKT4/OKT8 killing o though this has been reported. ${ }^{5}$ In contrast, cyto-s toxicity at $37^{\circ} \mathrm{C}$ was greater for OKT8 cells, and this was associated with a significant reduction in then fraction of OKT4 and OKT8 cells killed. There was also a significant inverse correlation between OKT $4 B$ OKT8 serum killing and the OKT4/OKT8 cell ration (i.e.. at $37^{\circ} \mathrm{C}$ ). The data showed that the lower cytotoxicity towards unfractionated T cells at $3 \neq 0$ (as compared with $15^{\circ} \mathrm{C}$ ) was due predominantly a reduction in toxicity for OKT4 positive cells. Tिe finding of significant $\mathrm{OKT} 8$ cytotoxicity at $37^{\circ} \mathrm{C}$ supported the view that LCA may contribute to the suppressor cell deficiencies observed in autoimmune? diseases. Some groups have shown that antagonismฉ of suppressor cell function resides in the $\operatorname{IgC} \vec{b}$ fraction of SLE serum, which includes the warm? reactive lymphotoxins. "Kinetic studies were per? formed at $15^{\circ} \mathrm{C}$ to allow direct comparison with the standard lymphocytotoxin assay. At $37^{\circ} \mathrm{C}$, inhibitior of shedding or internalisation of lymphocytotoxin or both, regardless of the presence of inhibitors of metabolism and cytoskeletal function, appeare incomplete as both IgM binding and lymphocytes killing were significantly lower than observed with the same sera at $15^{\circ} \mathrm{C}$. These inhibitors were able to increase killing at $37^{\circ} \mathrm{C}$ compared with that observe with CFD alone, however. A cumulative, non specific toxic effect of these reagents is unlikely a o they did not change the toxicity of normal sera at $15^{\circ} \mathrm{C}$ and $37^{\circ} \mathrm{C}$ and of SLE sera at $15^{\circ} \mathrm{C}$. Winfield $e$, al used semiquantitative data from a fluorescence activated cell sorter in similar experiments, and the also found no recovery of $\mathrm{IgM}$ binding at $37^{\circ} \mathrm{C}$ in the presence of cytoskeletal and metabolic inhibitors. They did not investigate the influence of these reagents on cell killing, however.

Before the Scatchard analysis the interactio between IgM antibody and lymphocyte surface waक्ष 
shown to be reversible (Fig. 3), with comparable rates of dissociation being found in both normal and lupus derived IgM.

A quantitative analysis of IgM binding to the surface of subsets of normal $T$ lymphocytes showed that both normal and SLE sera contained molecules that bound with high affinity (i.e., $\mathrm{Kd}$ of $1-6 \times 10^{-8}$ $\mathrm{mol} / \mathrm{l})$. SLE sera contained a much higher proportion of these molecules, however. IgM in lupus sera showed a saturable binding response, and at the highest concentration of free IgM there was actually a decrease in surface bound antibody. This was consistent with observations in infectious mononucleosis, ${ }^{13}$ which showed that dilution of lymphocytotoxic sera could lead to enhanced (rather than reduced) lymphocyte killing. This was postulated to result from non-specific inhibition of binding of cytotoxic molecules at high serum concentrations. The binding data for NHS and SLE sera gave values for $\mathrm{Kd}$ of $1-6 \times 10^{-8} \mathrm{~mol} / \mathrm{l}$ and up to $178000 \mathrm{IgM}$ molecules bound per cell. No significant difference between binding of IgM to OKT4 and OKT8 positive cells was apparent. Bound/free ratios were $<0 \cdot 01$, suggesting that only a small proportion of IgM was able to bind tightly to the lymphocyte surface, possibly leading to overestimation of the $\mathrm{Kd}$. It should also be emphasised that the calculation of the data in Table 1 assumed an equal number of sites per cell, though individual cell surfaces probably have different capacities (see below). As we found half saturation of binding to occur at $<10^{-7} \mathrm{~mol} / \mathrm{l}$ in vitro, most binding sites on lymphocytes would be expected to be occupied at the high concentration of IgM found in serum, and, indeed, Winchester et al noted that a high percentage of lymphocytes in some patients were coated with immunoglobulin.2 A selective decrease in brightly stained $\mathrm{T}$ cells as measured by fluorescence activated cell sorter has been described, ${ }^{14}$ emphasising the potential for in vivo processes to modify the interaction between $T$ cell and lymphocytotoxin.

A small number of the IgM reactive lymphocyte molecules, detected by immunoblotting techniques, were identified as surface antigens, i.e., they were absorbed by living cells under conditions which remove virtually all lymphocytotoxic activity from test serum. Solid phase immunoblotting methods have been criticised on the grounds that they may detect antibody/antigen interactions of low affinity, and thus of questionable importance in vivo. ${ }^{15}$ This is because of the amplification of assay sensitivity by the immobilisation of antigen, which leads to an increase in avidity. Some of the interactions detected probably are of low affinity, though autoantibodies are commonly found in normal serum. ${ }^{16}$ We were justified in attributing biological importance to the interactions reported in Table 2, however, because (a) IgM binding to the lymphocyte surface had an average $\mathrm{Kd}$ of $\leqslant 6 \times 10^{-8} \mathrm{~mol} / \mathrm{l}$, and $(b)$ the removal of IgM antibody by interaction with living cells was, by definition, a physiological process. In some cases a significant reduction rather than a total removal of a band was seen. This was attributable to partial shedding of the multivalent antibody-antigen complex, which was not preventable even at $4^{\circ} \mathrm{C}$ in the presence of azide. Other low affinity interactions may also have been present. Each SLE serum sample used in this study of surface antigens had lymphocytotoxicity of $>80 \%$, yet showed wide differences in the numbers and molecular weights of surface reactive autoantibodies. This explains the lack of a close correlation between LCA and IgM binding which we have demonstrated in this report.

Further work will clarify the importance of the various surface antigens through their association with disease severity or degree of lymphocyte dysfunction (as has been done for the many intracellular autoantigens found in SLE ${ }^{17}$ ). The differences noted between various SLE sera emphasised the view that lymphocyte autoantibodies do not, in this disease, result from non-specific polyclonal activation of the $\mathrm{B}$ cell repertoire.

The demonstration of tight binding between LCA and each lymphocyte subset and the observed correlation between LCA specificity and OKT4/ OKT8 cell ratio provide further evidence for the potential importance of this reaction in vivo. The data also demonstrate the influence of assay methodology on the analysis of LCA behaviour in vitro. Metabolic inhibition caused an increase in cell killing at $37^{\circ} \mathrm{C}$ without a significant change in IgM binding; this presumably reflects more efficient complement function at physiological temperatures. Finally, the observation that different surface antigens are targeted in individual patients suggests the potential for a range of functional effects on the $\mathrm{T}$ lymphocyte and a means of monitoring clinical lupus activity.

The figures were produced by the Department of Medical Illustration. University of New South Wales and teaching hospitals.

\section{References}

1 Mittal K K, Rossen R D, Sharp J T, Lidsky M D, Butler W T. Lymphocyte cytotoxic antibodies in systemic lupus erythematosus. Nature 1970; 225: 1255-6.

2 Winchester R J, Winfield J B, Siegal F, Wernet P, Bentwich F, Kunkel H G. Analysis of lymphocytes from patients with rheumatoid arthritis and systemic lupus erythematosus: occurrence of interfering cold-reactive antilymphocyte antibodies. J Clin Invest 1974; 54: 1082-92.

3 Morimoto C, Rienherz E L, Abe T, Homma M, Schlossman S F. Characteristics of anti-T cell antibodies in SLE: evidence for selective reactivity with normal suppressor cells defined by 
monoclonal antibodies. Clin Immunol Immunopathol 1980; 16: 474-84.

4 Yamada A, Cohen P L, Winfield J B. Subset specificity of antilymphocyte antibodies in systemic lupus erythematosus. Preferential reactivity with cells bearing the T4 and autologous erythrocyte receptor phenotypes. Arthritis Rheum 1985; 28: 262-70.

5 Morimoto C, Rienherz E L. Distaso J A. Steinberg A D. Schlossman S F. Relationship between systemic lupus erythematosus $T$ cell subsets, anti- $T$ cell antibodies, and $T$ cell functions. J Clin Invest 1984; 73: 689-700.

6 Cohen A S. Canuso J J. Criteria for the classification of systemic lupus erythematosus status. Arthritis Rheum 1972: 15: $540-3$.

7 Terasaki P I. McClelland J D. Microdroplet assay of human scrum cytotoxins. Nature 1964: 204: 998-1000).

8 Marchalonis J J. An enzymic method for trace iodination of immunoglobulins and other proteins. Biochem J 1969: 113: 299-305.

9 Lacmmli U K. Cleavage of structural proteins during the assembly of the head of bacteriophage Tt. Nature 1970: 227: $681-4$.

10 Towbin H. Stachelin T. Gordon J. Electrophoretic transfer of proteins from polvacrylamide gels to nitrocellulose sheets: procedure and some applications. Proc Natl Acad Sci US 1979; 76: $4350-4$.

11 Okudaira K. Tanimoto K. Horiuchi Y. Effect of antilympho cyte antibody in SLE on in vitro Ig synthesis. Clin Immun Immunopathol 1981: 21: 162-71.

12 Winficld J. Shaw M. Minota S. Modulation of $\operatorname{lgM}$ anto lymphocyte antibody-reactive $T$ cell surface antigens in systeme lupus erythematosus. J Immunol 1986: 136: 3246-53.

13 Peake P. Charlesworth J A. Pussell B A. Normal human serur inhibits the lymphocytotoxicity of sera from patients wita infectious mononucleosis. Clin Exp Immunol 1983; 52: 671-70

14 Steinberg A D. Klassen L W. Budman D R. Williams G W. Immunofluorescence studies of anti-T-cell antibodies and T. cells in systemic lupus erythematosus. Arthritis Rheum 1979: 22: $11+22$.

15 Eilat D. Anti-DNA antibodies: problems in their study and interpretation. Clin Exp Immunol 1986: 65: 215-22.

16 Guilbert B. Dighiero G. Avrameas S. Naturally occurrini antibodies against nine common antigens in human sera. Detection. isolation and characterization. J lmmunol 1982: 128 2279-83.

17 Christian C. Elkon K. Autoantibodics to intracellular proteins Clinical and biological significance. Am J Med 1986: 80: 53-6으 